\title{
Effectiveness of Antiemetic Treatment Among Breast Cancer Patients in Inpatient Unit Sardjito General Hospital
}

\author{
Marlita Putri Ekasari ${ }^{1}$, Nanang Munif Yasin ${ }^{2}$, Susi Ari Kristina ${ }^{1}$, and \\ Zullies Ikawati
}

${ }^{1}$ Laboratory of Pharmacy Management and Community Pharmacy, Faculty of Pharmacy, University Gadjah Mada Unit III, $2^{\text {nd }}$ Floor, Sekip Utara, Sinduadi, Mlati, Sleman, Daerah Istimewa Yogyakarta, 5528, Indonesia

${ }^{2}$ Laboratory of Clinical Pharmacy and Pharmacotherapy, Faculty of Pharmacy, Universitas Gadjah Mada, Unit V, $2^{\text {nd }}$ Floor, Sekip Utara, Sinduadi, Mlati, Sleman, Daerah Istimewa Yogyakarta, 55281, Indonesia

\section{Abstract}

Nausea and vomiting are chemotherapy adverse events that influence breast cancer patient's quality of life. Antiemetic regimen as premedication was given to prevent those

Corresponding Author: Marlita Putri Ekasari

marlita.putri.ekasari@gmail.com

Received: 10 November 2018

Accepted: 6 January 2019

Published: 10 March 2019

Publishing services provided by Knowledge E

(c) Marlita Putri Ekasari et al. This article is distributed under the terms of the Creative Commons Attribution License, which permits unrestricted use and redistribution provided that the original author and source are credited.

Selection and Peer-review unde the responsibility of the UASC Life Sciences 2016 Conference Committee. adverse events and need to be evaluated. This study aimed to present the effectiveness of antiemetic treatment among breast cancer patients in the inpatient unit, Rumah Sakit Umum Pusat Dr. Sardjito [Central Public Hospital Dr. Sardjito] Yogyakarta, Indonesia. A cohort study was used in this study during July 2008 to January 2009. Thirty-one breast cancer patients, who are receiving antiemetic therapy and having no disease that induced nausea and vomiting were involved, signed informed consent and had been followed by before-post chemotherapy. The data was gained from chemotherapy and antiemetic regimens, medical records, patient's interviews, and finally analyzed using descriptive, evaluative approach. This study presented that antiemetic treatment among breast cancer patient in the inpatient unit was $61.40 \%$ ineffective reducing incidence of nausea vomiting events. The majority of cases of nausea and vomiting onset among patients were acute-delayed (56.2 \%; $52.0 \%$ ), severity of nausea and vomiting laid mostly in the second level (54.54 \%; $52.00 \%$ ), and appropriateness antiemetic treatment complied to NCCN guideline 2007 and ASCO guideline 2006 was only applied in low emetic risk of chemotherapy-induced nausea and vomiting. Antiemetic regimens that had been implemented need to be evaluated because of majority cases of nausea and vomiting were the acute-delayed type, level two of severity and inappropriateness of international guideline. This study should be followed with the future study of the evaluation of the effectiveness of another medication supported the patient in receiving chemotherapy.

Keywords: Antiemetic, Breast cancer, Effectiveness, Nausea, Vomiting.

1. Introduction

About 7600000 from 58000000 people died caused by cancer, and $70 \%$ of them lived in low-middle income countries with minimum prevention, therapy availability, and accessibility. The number of death caused by cancer projected increasing by 11400000 
in 2030. In Indonesia, breast cancer was lied together in five top highest rank cancer case among women $[1,2]$.

Chemotherapy is selected as the main therapy for treated breast cancer [3, 4]. Nausea and vomiting are the adverse effects of chemotherapy that frequently reported and negatively affected patients, especially in their daily life, the quality of life of patients and the adherence to chemotherapy. Uncontrolled nausea vomiting would lead to the worsen patient's condition, decreased patient's appetite, poor nutritional status, dehydration, electrolyte disturbances and pneumonia [5]. To overcome it, patient in undergoing chemotherapy commonly used antiemetic as prophylaxis [6].

Based on the data above, the treatment of nausea and vomiting among patients with breast cancer need to be evaluated especially the effectiveness of its therapy for supporting the quality life of patients. So, assessing the effectiveness of nausea and vomiting treatment is very important, to know the extent to which the management of these therapies successfully implemented and to see the treatment will bring great benefit to the patients or not.

\section{Methods}

This study aimed to present the effectiveness of antiemetic treatment among breast cancer patients in the inpatient unit, Rumah Sakit Umum Pusat - RSUP Dr. Sardjito (Central Public Hospital Dr. Sardjito) Yogyakarta, Indonesia. Central Public Hospital Dr. Sardjito Yogyakarta was chosen as study location because it is one of referral hospital for cancer in Indonesia, especially in Central Java Province and D.I. Yogyakarta Province. Breast cancer was in the second top rank of cases in this hospital from 2003 to 2004 [7].

All respondents were breast cancer patients who voluntarily recruited during July 2008 to January 2009 and met the inclusion criteria such as (i) receiving antiemetic therapy, (ii) having no disease that induced nausea and vomiting, (iii) signed informed consent, (iv) having completed medical records, chemotherapy protocols, and (v) having willingness to be interviewed. About 55 patients (110 cases) were obtained and signed informed consent, only 31 patients (57 cases) were enrolled with completed data.

This study used a cohort study with descriptive evaluation approach. The data was gained prospectively. The instruments of this study were semi-structured interview protocols, Card of Patient's Medication (KIPO), informed consent, chemotherapy protocols, and patient's medical records. The effectiveness of antiemetic regimens 
was evaluated by comparing the level of emetic severity between pre- and postchemotherapy. Antiemetic regimens also evaluated with the appropriateness to the ASCO (2006) guideline and NCCN (2007) guideline.

Ethical clearance (KE/FK/208/EC) - the approval to conduct this study - was obtained from the UGM ethical committee, and permission (LB.02.01.4.9082-2) was granted from RSUP Dr. Sardjito. Written-informed consent was obtained from all of the participants who agreed to participate in the study. Participants were also assured of the confidentiality of their identity.

The strength of the study could describe the pattern of antiemetic therapy and showed the effectiveness of antiemetic regimens to prevent nausea and vomiting among breast cancer patients. The limitations of this study were [1] the study was conducted from July 2008 to January 2009, need more extended duration of the program; [2] incomplete data pre and post-chemotherapy due to inconsistence patient's treatment schedule. It made 26 patients who potential and having a willingness to join this study failed to be followed up.

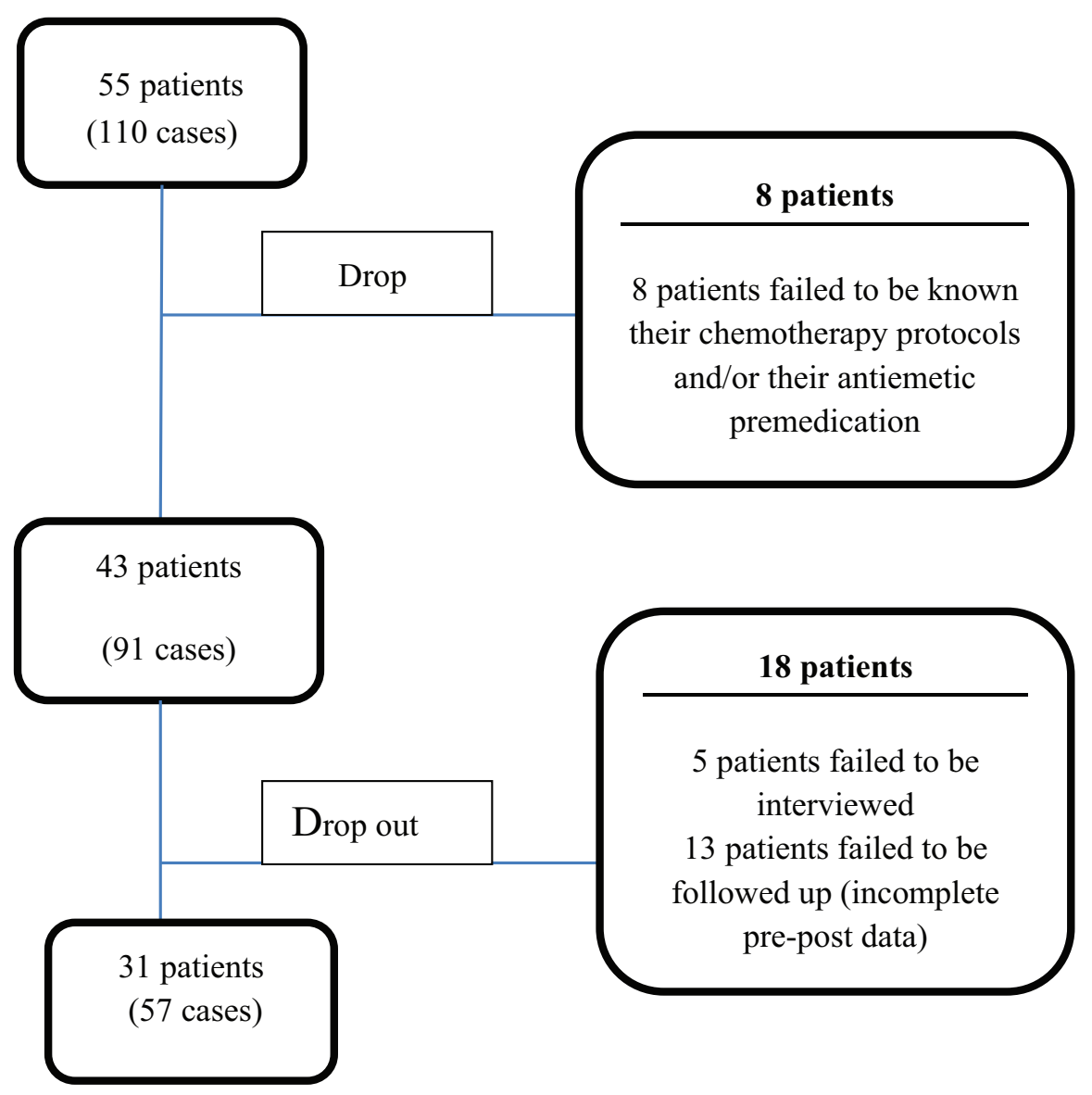

Figure 1: Flow Chart of Patients who recruited in this study. 


\section{Results}

Breast cancer patients received various chemotherapy regimens (low, moderate, and high emetic chemotherapy agents) in four or six cycles. All of them were women (100 $\%)$, with majority $50 \mathrm{yr}$ to $59 \mathrm{yr}(45.2 \%)$. It was relevant with data from Canadian Cancer Statistics in 2007 [8]. Most of them were menopause (83.9\%) and in the advance stages of cancer (81.2\%). This fact appeared due to the delayed diagnosis of cancer. Mostly, the patient got anemia in the second cycle of their chemotherapy treatment (13.46\%). This hematology complication affected the type and duration of therapy and malignant stages due to the decision having a blood transfusion. The family history of breast cancer patients have been traced, only five patients $(16.13 \%)$ showed that their mother or sister who died because of cancer.

TABLE 1: Characteristics of breast cancer patients who received chemotherapy in inpatient unit, Central Public Hospital Dr. Sardjito July 2008 to January 2009.

\begin{tabular}{|c|c|c|}
\hline Characteristics & $n(n=31)$ & Percentage (\%) \\
\hline \multicolumn{3}{|l|}{ Age } \\
\hline $30 \mathrm{yr}$ to $39 \mathrm{yr}$ & 3 & 9.68 \\
\hline $40 \mathrm{yr}$ to $49 \mathrm{yr}$ & 12 & 38.71 \\
\hline $50 \mathrm{yr}$ to $59 \mathrm{yr}$ & 14 & 45.16 \\
\hline $60 \mathrm{yr}$ to $69 \mathrm{yr}$ & 1 & 3.23 \\
\hline $70 \mathrm{yr}$ to $79 \mathrm{yr}$ & 1 & 3.23 \\
\hline \multicolumn{3}{|l|}{ Sex } \\
\hline Male & 0 & 0.00 \\
\hline Female & 31 & 100.00 \\
\hline \multicolumn{3}{|c|}{ Stages of Breast Cancer Severity } \\
\hline IIB & 2 & 6.45 \\
\hline IIIB & 13 & 41.94 \\
\hline IV & 13 & 41.94 \\
\hline Residive & 4 & 12.90 \\
\hline \multicolumn{3}{|c|}{ Family History of Breast Cancer } \\
\hline Yes & 5 & 16.13 \\
\hline No & 26 & 83.87 \\
\hline \multicolumn{3}{|l|}{ Fertility } \\
\hline Menstruation & 5 & 16.13 \\
\hline Menopause & 26 & 83.87 \\
\hline \multicolumn{3}{|l|}{ Age of Menarche } \\
\hline$<12 \mathrm{yr}$ & 0 & 0.00 \\
\hline $12 \mathrm{yr}$ to $14 \mathrm{yr}$ & 14 & 45.16 \\
\hline$>14 \mathrm{yr}$ & 4 & 12.90 \\
\hline Not Remember/Not Known & 13 & 41.94 \\
\hline
\end{tabular}


Metoclopramide, antagonist dopamine-2 (26.82 \%) was used as antiemetic premedication among patient who got chemotherapy regimens with low emetic risk. Mostly, metoclopramide as single medication (10 cases) blocked dopamine-2 receptor to prevent nausea and vomiting: dexamethasone (25.7\%) and diphenhydramine (18.8\%) commonly used as a combination with antagonist dopamine- 2 or antagonist $5 \mathrm{HT}-3$ receptor.

TABLE 2: Chemotherapy and antiemetic regimens therapy variation in inpatient unit, Central Public Hospital Dr. Sardjito July 2008 to January 2009.

\begin{tabular}{|c|c|c|}
\hline Medication & N (31 Patients, 57 cases) & (\%) \\
\hline \multicolumn{3}{|l|}{ Cycle } \\
\hline First Cycle & 50 & 87.72 \\
\hline Second Cycle & 7 & 12.28 \\
\hline \multicolumn{3}{|l|}{ Cancer Regimens } \\
\hline AC (Cyclophosphamide + Doxorubicin) & 3 & 9.68 \\
\hline AT (Doxorubicin + Paclitaxel) & 12 & 38.71 \\
\hline TC (Paclitaxel + Carboplatin) & 14 & 45.16 \\
\hline CE (Cyclophosphamide + Ephyrubicine) & 1 & 3.23 \\
\hline T (Paclitaxe) & 1 & 3.23 \\
\hline \multicolumn{3}{|l|}{ Type of Antiemetic Regimens } \\
\hline Dopamine 2 antagonist : Metoclopramid (i.v) & 47 & 26.86 \\
\hline 5HT3 antagonist : Ondansetron (i.v.) & 10 & 5.71 \\
\hline Corticosteroid : Dexamethasone (i.v.)/(p.o.) & $44 / 1$ & $25.14 / 0.57$ \\
\hline Antihistamine : Diphenhydramine (i.v.) /(i.m..) & $31 / 2$ & $17.71 / 1.14$ \\
\hline Proton Pump Inhibitor : Ranitidine (i.v.) & 40 & 22.86 \\
\hline \multicolumn{3}{|l|}{ Variation of Antiemetic regimens } \\
\hline One drug (M /D/O) & $12(10 / 1 / 1)$ & \\
\hline Combination of two drugs (OD) & $5(5)$ & \\
\hline Combination of three drugs (MDR / ODR / ODD) & $7(5 / 1 / 1)$ & \\
\hline Combination of four drugs (ODRP / MTRP / MODR) & 33 91/31/1) & \\
\hline
\end{tabular}

All of breast cancer patients experienced nausea, vomiting, and both of events. About $61.4 \%$ patients still perceived nausea and/or vomiting, only $38.60 \%$ were free from those events. See table 3. If we take a look in details, the cases of nausea-induced chemotherapy (33 cases) were higher than vomiting-induced chemotherapy (25 cases). The severity levels of nausea and/or vomiting were presented mostly in second level (from 5 levels) for nausea (54.45 \%) and vomiting (52.00\%).

The onset of nausea and vomiting were presented separately in 2 figures, Fig. 2. Patients who received high emetic risk of chemotherapy regimens experienced vomiting in several hours after chemotherapy in first day (acute). Low-moderate emetic risk 
TABLE 3: Cases of nausea and vomiting compared to the emetic risk of chemotherapy in inpatient unit, Central Public Hospital Dr. Sardjito July 2008 to January 2009.

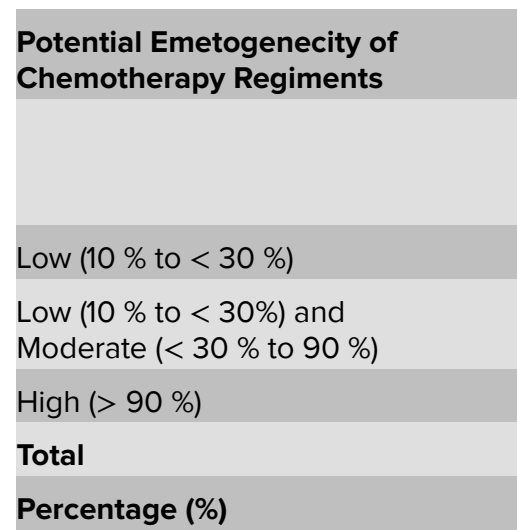

Potential Emetogenecity of Chemotherapy Regiments

TABLE 4: Level of severity nausea and vomiting of breast cancer patients in inpatient unit, Central Public Hospital Dr. Sardjito July 2008 to January 2009.

\begin{tabular}{|l|c|c|c|c|c|}
\hline Patient's Condition & \multicolumn{5}{|c|}{ Level of Severity [n (\%)] } \\
\hline Nausea $(n=33)$ & $\mathbf{1}$ & $\mathbf{2}$ & $\mathbf{3}$ & $\mathbf{4}$ & $\mathbf{5}$ \\
\hline Vomiting $(n=25)$ & $13(39.39)$ & $18(54.55)$ & $2(6.06)$ & $0(0.00)$ & $0(0.00)$ \\
\hline
\end{tabular}

TABLE 5: The Antiemetic regimens usage of breast cancer patients in inpatient unit, Central Public Hospital Dr. Sardjito July 2008 to January 2009.

\begin{tabular}{l|l|}
\hline Emetogenicity Level & $\begin{array}{c}\text { Chemotherapy } \\
\text { Regiments }\end{array}$ \\
\hline $\begin{array}{l}\text { Low }(10 \% \text { to }<30 \%) \\
\text { Low and Moderate } \\
(10 \% \text { to }<30 \%) \\
(30 \% \text { to } 90 \%)\end{array}$ & \begin{tabular}{c} 
T Regiments $(n=10)$ \\
\hline High $(>90 \%)$
\end{tabular} \\
\hline TC Regiments $(n=20)$
\end{tabular}

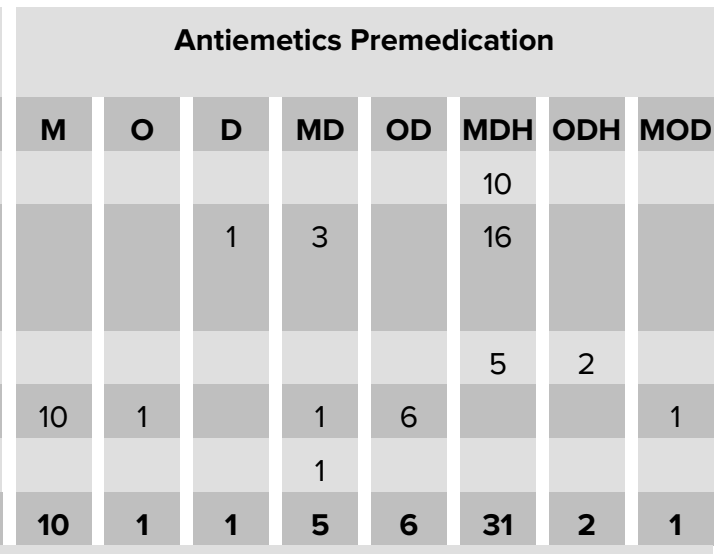

Notes: T (Paclitaxel); AT (Doxorubicine + Paclitaxel); TC (Paclitaxel + Carboplatine); AC (Cyclophosphamide + Carboplatine); CE (Cyclophosphamide + Epirubicine); M (Metoclopramide); O (Ondansetron); D (Dexamethasone); MD (Metoclopramide + Dexamethasone); OD (Ondansetron + Dexamethasone); MDH (Metoclopramide + Dexamethasone + Dyphenhydramine); ODH (Ondansetron + Dexamethasone + Dyphenhidramine) + MOD (Metoclopramide + Ondansetron + Dexamethasone)

extremely induced nausea and vomiting in the first day and followed more than $5 \mathrm{~d}$ (delayed).

The antiemetic, its relation of emetic risk level and chemotherapy regimens that had been chosen presented well in Table 5. Patient from low to high had taken the antiemetic 


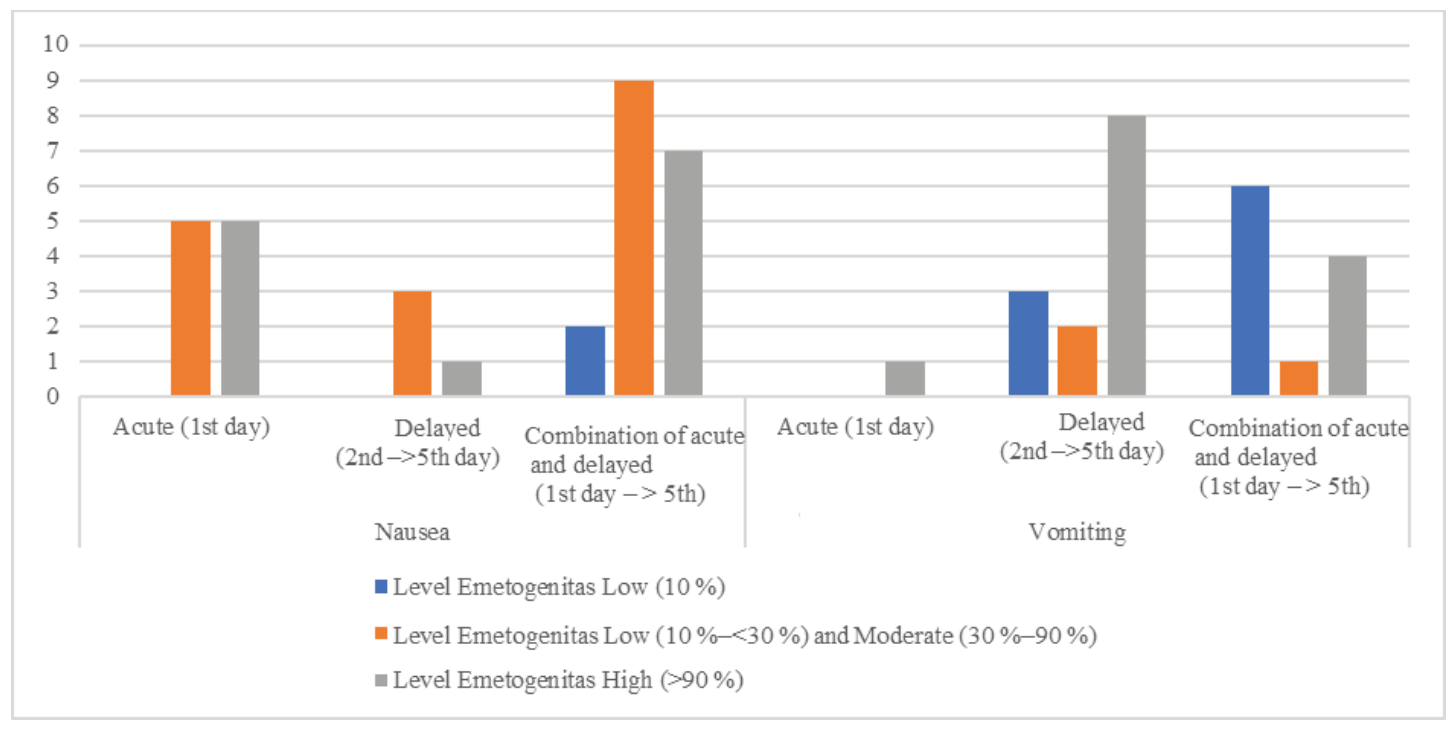

Figure 2: The onset of nausea versus vomiting compared to the level of emetogenecity of chemotherapy regimens.

tended to be varied. In low emetic risk level of chemotherapy regimens, there is no variation of antiemetic, all patients treated with a combination of metoclopramide, dexamethasone, and diphenhydramine. For low and moderate risk level, several patients got single medication (dexamethasone), three of them got a combination of metoclopramide and dexamethasone, and the rest of it treated with metoclopramide, dexamethasone and diphenhydramine or ondansetron, dexamethasone and diphenhydramine. Variation of chemotherapy agents which is at high risk level was almost the same with lowmoderate risk level, but metoclopramide had been dominated as the single medication.

The emetic treatment as premedication presented was ineffective (64.92 \%) reducing the level and cases of nausea and/or vomiting-induced-chemotherapy. It strongly related to inappropriateness with NCCN 2007 and ASCO 2006 which added as a negative factor. Only one part of NCCN guideline that met the implementation, metoclopramide without or with dexamethasone, diphenhydramine, and prochlorperazine.

\section{Discussion}

Reducing the cases of nausea and/or vomiting after chemotherapy difficult to be attempted. Table 3 presented the number of cases and its categories. Those data were in line with Germany cancer center study, about $62.5 \%$ nausea events had been recorded compared to the vomiting events which only shown about $26 \%$ [9]. Acute onset, delayed onset or both events of nausea and vomiting appeared clearly. It showed that those events hardly avoided [10]. 
TABLE 6: The effectiveness of antiemetic regimens.

\begin{tabular}{|c|c|c|c|c|}
\hline \multirow[t]{2}{*}{ Antiemetic Premedication } & \multirow[t]{2}{*}{ Emetic Risk } & \multicolumn{3}{|c|}{ The Effectiveness of Antiemetic } \\
\hline & & Ineffective & Effective & Total \\
\hline Metoclopramide & High & 5 & 5 & 10 \\
\hline Ondansetrone & High & 1 & - & 1 \\
\hline Dexamethasone & Low-Moderate & 1 & - & 1 \\
\hline \multirow{2}{*}{$\begin{array}{l}\text { Metoclopramide + } \\
\text { Dexamethasone }\end{array}$} & Low-Moderate & 3 & - & 3 \\
\hline & High & 2 & - & 2 \\
\hline $\begin{array}{l}\text { Ondansetrone + } \\
\text { Dexamethasone }\end{array}$ & High & 5 & 1 & 6 \\
\hline \multirow{2}{*}{$\begin{array}{l}\text { Metoclopramide }+ \\
\text { Dexamethasone }+ \\
\text { Dyphenhidramine }\end{array}$} & Low & 3 & 7 & 10 \\
\hline & Low-Moderate & 14 & 7 & 21 \\
\hline $\begin{array}{l}\text { Ondansetrone + } \\
\text { Dexamethasone + } \\
\text { Dyphenhidramine }\end{array}$ & Low-Moderate & 2 & - & 2 \\
\hline $\begin{array}{l}\text { Metoclopramide + } \\
\text { Ondansetrone + } \\
\text { Dexamethasone }\end{array}$ & High & 1 & - & 1 \\
\hline Total & & 37 & 20 & 57 \\
\hline
\end{tabular}

Patients who got chemotherapy regimens with high emetic risks (> $90 \%$ ) tended to experience nausea and vomiting rather than the combination of low-moderate risks (10 $\%$ to $30 \%, 30 \%$ to $90 \%$ ) and low risks regimens (10\% to $30 \%$ ). Table 5 showed that the patients who got high emetic chemotherapy regimens ( $A C$ and $C E$ regimens) treated mostly with metoclopramide only (10 cases) which did not appropriate with the ASCO or NCCN Guideline [11]. Low dose metoclopramide stimulated gastric emptying, in high dose, metoclopramide worked to stop the stimulation to the brain which can cause nausea vomiting [5]. Blocking dopamine-2 was not only enough because of the complexity of emesis induced chemotherapy. They were undertreated and should receive a combination of antiemetic drug therapy to prevent nausea and/or vomiting. Dexamethasone, ranitidine, and diphenhydramine are needed to be added in the antiemetic regimens [11].

Contrary, patients who received low risks chemotherapy regimens, $T$ regimens, 10 cases) found over-treated. The patient got a combination of antiemetic premedication, metoclopramide, dexamethasone, and diphenhydramine. Only seven cases from 10 cases successfully reduced the level severity of nausea and vomiting events. This fact showed that antiemetic premedication that had been provided to the patients did not meet the therapeutic goals. 
The majority of antiemetic regimens provided in combination in order to increase the efficacy of drugs reduced the toxicity of antiemetic therapy and preventing the adverse effect of chemotherapy. Metoclopramide or Ondansetron combined with another

TABLE 7: Antiemetic regimens that had been received and its appropriateness to the ASCO guideline and NCCN guideline.

\begin{tabular}{|c|c|c|c|c|c|}
\hline Emetic Risk & $\begin{array}{l}\text { Antiemetic } \\
\text { Premedication }\end{array}$ & $\begin{array}{l}\text { ASCO (2006) } \\
\text { Guideline }\end{array}$ & $\begin{array}{l}\text { Appropriate } \\
(\sqrt{ }) \text { or Not }(X)\end{array}$ & $\begin{array}{l}\text { NCCN (2007) } \\
\text { Guideline }\end{array}$ & $\begin{array}{c}\text { Appropriate } \\
(\sqrt{ }) \text { or Not }(X)\end{array}$ \\
\hline $\begin{array}{l}\text { Low } \\
\text { (<10 \% to } 30 \%)\end{array}$ & $\begin{array}{l}\text { Metoclopramide+ } \\
\text { Dexametha- } \\
\text { sone+ } \\
\text { Dyphenhidramine }\end{array}$ & Dexamethasone & $x$ & $\begin{array}{l}\text { Metoclopramide } \\
\text { +/- (Dexametha- } \\
\text { sone / } \\
\text { Dyphen- } \\
\text { hidramine / } \\
\text { Procloprazyne) }\end{array}$ & $\sqrt{ }$ \\
\hline \multirow[t]{4}{*}{$\begin{array}{l}\text { Low } \\
\text { (< } 10 \% \text { to } 30 \%)+ \\
\text { Moderate } \\
\text { (30\% to } 90 \%)\end{array}$} & Dexamethasone & $\begin{array}{l}\text { Aprepitant + } \\
5 \text { HT3 Antagonist } \\
+ \\
\text { Dexamethasone }\end{array}$ & $x$ & $\begin{array}{l}\text { Aprepitant + } \\
5 \text { HT3 } \\
\text { Antagonist + } \\
\text { Dexamethasone } \\
\text { +/- Lorazepam }\end{array}$ & $x$ \\
\hline & $\begin{array}{l}\text { Metoclopramide } \\
+ \\
\text { Dexamethasone }\end{array}$ & $\begin{array}{l}\text { a. } 5 \text { HT3 } \\
\text { Antagonist + } \\
\text { Dexamethasone } \\
\text { b. Aprepitant + } \\
\text { 5HT3 Antagonist } \\
+ \\
\text { Dexamethasone }\end{array}$ & $x$ & & $x$ \\
\hline & $\begin{array}{l}\text { Metoclopramide } \\
+ \\
\text { Dexamethasone } \\
+ \\
\text { Dyphenhidramine }\end{array}$ & & & & \\
\hline & $\begin{array}{l}\text { Ondansetrone + } \\
\text { Dexamethasone } \\
+ \\
\text { Dyphenhidramine }\end{array}$ & & & & \\
\hline \multirow[t]{5}{*}{ High (> $90 \%$ ) } & Metoclopramide & $\begin{array}{l}\text { Aprepitant + } \\
5 \text { HT3 Antagonist } \\
+ \\
\text { Dexamethasone } \\
\text { +/- Lorazepam }\end{array}$ & $x$ & $\begin{array}{l}\text { Aprepitant + } \\
5 \text { HT3 } \\
\text { Antagonist + } \\
\text { Dexamethasone } \\
\text { +/- Lorazepam }\end{array}$ & $x$ \\
\hline & $\begin{array}{l}\text { Ondansetrone + } \\
\text { Dexamethasone } \\
+ \\
\text { Dyphenhidramine }\end{array}$ & & $x$ & & $x$ \\
\hline & $\begin{array}{l}\text { Metoclopramide } \\
+ \\
\text { Dexamethasone }\end{array}$ & & $x$ & & $x$ \\
\hline & $\begin{array}{l}\text { Ondansetrone + } \\
\text { Dexamethasone } \\
+ \\
\text { Dyphenhidramine }\end{array}$ & & $x$ & & $x$ \\
\hline & $\begin{array}{l}\text { Metoclopramide } \\
+ \text { Ondansetrone } \\
+ \\
\text { Dexamethasone }\end{array}$ & & $x$ & & $x$ \\
\hline
\end{tabular}


medicine. Dexamethasone usually used in combination with high dose metoclopramide could reduce adverse reaction of metoclopramide (diarrhea) and might affect prostaglandin activity in the brain although the mechanism of action is not wellunderstood - some of the studies mentioned its action in potentiating antiemetic properties of $5 \mathrm{HT} 3$ agents [2]. Ranitidine (22.9\%) frequently needed to be added in nausea vomiting therapy by reducing acid secretion. The cytotoxic agent could damage gastric mucus up to gastrointestinal tract - Diphenhydramine commonly used as an additional medication to reduce the side effect of metoclopramide, extrapyramidal symptom [11].

All antiemetic regimens that had been provided to the breast cancer patient did not appropriate with NCCN and ASCO guideline. The aprepitant that had been recommended since 2003 was not available in Indonesia as the main reason [11, 12].

\section{Conclusions}

Antiemetic regimens were ineffective because of several factors, such as cases of nausea and vomiting still dominants (64.91\%) with the type of onset acute-delayed, level two of severity, and inappropriateness with NCCN (2007) standard and ASCO (2006) standard.

This study finding will be useful for Central Public Hospital Dr. Sardjito to have better services to breast cancer patients who are dealing with nausea and vomiting during chemotherapy treatment.

\section{Acknowledgments}

The authors thank all participants for sharing their time, their feeling, life stories, and their experience in dealing with nausea and vomiting and moreover cancer.

\section{References}

[1] WHO. Cancer [Internet]. 2008 [cited 2008 Dec 1]. Available from: http://www.who.int/ cancer/en/

[2] WHO. WHO's fight against cancer strategies that prevent, cure, \& care. 2008. p.3. [cited 2009 Feb 23] http://www.who.int/cancer/publications/fight_against_cancer/ en/ 
[3] TIM RS Kanker Dharmais. Penataksanaan kanker payudara terkini. [Implementing the latest breast cancer]. YOI, Yogyakarta; 2003. p. 87, 94. [in Bahasa Indonesia] https://books.google.co.id/books?id=YmfVskk6QOgC\&dq=Tim+Penanggulangan+ Dan+Pelayanan+Kanker+Payudara+Terpadu+Paripurna+R.S.+Kanker+Dharmais. +Penataksanaan+Kanker+Payudara+Terkini.+2003.\&hl=id\&source=gbs_navlinks_s

[4] National Cancer Institute. Nausea and vomiting (PDQ $\left.{ }^{\circledR}\right)$-health professional version [Internet]. 2008 [cited 2009 Jan 20]. Available from: https://www.cancer.gov/aboutcancer/treatment/side-effects/nausea/nausea-hp-pdq

[5] Alsagaff H. Kanker paru dan terapi paliatif. [Lung cancer and palliative therapy]. Surabaya, Airlangga Universitas Press; 1995. p. 143-144, 295-297. [in Bahasa Indonesia] https://books.google.co.id/books/about/ Kanker_paru_dan_terapi_paliatif.html?id=0LqQnQAACAAJ\&redir_esc=y

[6] DiPiro JT, Talbert RL, Yee GC, Matzkee GR, Wells BG, Posey M. Pharmacotherapy 7th ed. United States of America, The McGraw-Hill Companies; 2008. p. 295-297 http: //fac.ksu.edu.sa/sites/default/files/Pharmacotherapy_Handbook_7th_Edition.pdf

[7] As Shidiq FH. Profil pasien kanker payudara di RS Dr.Sardjito periode 2003-2004. [Profile of breast cancer patients in Dr. Sardjito Hospital period 2003-2004]. [Thesis]. Faculty of Medicine, Universitas Gadjah Mada Indonesia; 2006. p.17-18. [in Bahasa Indonesia]. [Unpublished].

[8] National Cancer Institute of Canada. Canadian cancer statistics [Internet]. Toronto, Canada; 2007. p. 116. Available from: www.canceradvocacy.ca/ann/special.html/ 4915/Canadian+Cancer+Statistics+2007.pdf

[9] Ihbe-Heffinger. The impact of delayed chemotherapy-induced nausea and vomiting on patients, health resource utilization and costs in German cancer centers. Ann Oncol [Internet]. 2004 Mar 1 [cited 2016 Dec 2014];15(3):526-536. Available from: http://annonc.oupjournals.org/cgi/doi/10.1093/annonc/mdh110

[10] Fabi A, Barduagni M, Lauro S, Portalone L, Mauri M, Marinis F. Is delayed chemotherapy-induced emesis well managed in oncological clinical practice? An observational study. Support Care Cancer [Internet]. 2003 Mar [cited 2016 Dec 14];11(3):156-61. Available from: http://www.ncbi.nlm.nih.gov/pubmed/12618925

[11] Ettinger DS, Bierman PJ, Bradbury B, Comish CC, Ellis G, Ignoffo RJ, et al. Antiemesis: Clinical practice guidelines in OncologyTM. JNCCN J Natl Compr Cancer Netw [Internet]. 2007;5(1):12-33. https://www.ncbi.nlm.nih.gov/pubmed/19460282

[12] Jordan K, Kasper C, Schmoll H-J. Chemotherapy-induced nausea and vomiting: Current and new standards in the antiemetic prophylaxis and treatment. Eur J Cancer [Internet]. 2005 Jan [cited 2016 Dec 14];41(2):199-205. http://www.ncbi.nlm.nih.gov/ pubmed/15661543 